Available Online at EScience Press
Journal of Arable Crops and Marketing
Arable Crops
inarketing
https://esciencepress.net/journals/JACM

\title{
Application of Silica Gel on Growth and Yield of Camelina sativa L.
}

\author{
${ }^{a}$ Ehsan Ul Haq*, aFayyaz Ul Hassan, ${ }^{a}$ Mukhtar Ahmed, ${ }^{b}$ Abdul Mannan Hamzah, ${ }^{b}$ Fahad Ali Fayyaz, \\ ${ }^{a}$ Rafique Ahmed, aMuslim \\ a Department of Agronomy, PMAS Arid Agriculture University, Rawalpindi, Pakistan. \\ c Department of Entomology, PMAS Arid Agriculture University, Rawalpindi, Pakistan.
}

Corresponding Author: Ehsan Ul Haq, Email: ehsanulhaq620@gmail.com

ART ICLE IN F O

\section{Article History}

Received: July 29, 2020

Revised: October 20, 2020

Accepted: October 29, 2020

Keywords

Camelina sativa

Silica Gel

Relative water content

\section{A B S T R A C T}

The present study was designed to evaluate the effect of different concentrations of Silica gel on the growth and yield of Camelina sativa. A pot experiment was laid out in Completely Randomized Design (CRD) with three replications at Nanotechnology Laboratory, Department of Agronomy, PMAS Arid Agriculture University Rawalpindi. The experiment consisted of 4 levels $(0.15 \mathrm{mg} / \mathrm{g}, 0.30 \mathrm{mg} / \mathrm{g}, 0.45 \mathrm{mg} / \mathrm{g}$ and 0.60 $\mathrm{mg} / \mathrm{g}$ ) of each mentioned nutrient along with control. The data were recorded and analyzed according to recommended procedure for following parameters viz., germination $\%$, root and shoot length $(\mathrm{cm})$, root and shoot biomass $(\mathrm{g})$, relative water content of leaf and leaf membrane stability index. It was observed that $0.60 \mathrm{mg} / \mathrm{g}$ silica gel application increased the seed germination (80\%), root length $(6.67) \mathrm{cm}$, shoot length (35.33) cm, root biomass (1.7) g, shoot biomass (5.57) g, relative water content of leaf (0.69) and leaf membrane stability index (0.07). The study concluded that significant effect of silica gel application is crucial and important to improve vegetative attributes of false flax.

\section{INTRODUCTION}

Agriculture is the backbone of country's economy and plays vital role in economic growth and development. Oilseed crops contribute second highest share in Pakistan's economy after cereals (Bayer, 2010). Edible oil is used in daily household and commercial food preparation as an important and essential ingredient across the country. Unfortunately, our agriculture based economy is unable to meet the domestic edible oil production locally. The deficiency is now progressing at alarming rate due to rapid increase in population ((Abbas et al., 2010).

Camelina (false flax / gold of pleasure) scientifically termed as Camelina sativa $\mathrm{L}$. is an oil seed crop of brasicaceae family (Wariach et al., 2013) with low agronomic-input use (Putnum et al., 1993). It has the unique and health favored fatty acid patterns, composed up of higher level linolenic acid and comparatively low erucic acid concentration (Zubr and Matthaus, 2002). The oil extracted from seed is the key product from Camelina, which vary among cultivar 320 and $460 \mathrm{~g} \mathrm{~kg}^{-1}$ (Vollman et al., 2007). Camelina seed meal fluctuates from 390 to 470 $\mathrm{g} \mathrm{kg}^{-1}$ for Crude protein content (Zubr, 2003) and glucosinolates varies between 13.2 and $36.2 \mathrm{mmol} \mathrm{g}^{-1}$ dry seed (Schuster and Friedt 1998). Moreover, the Camelina has economically feasible oil content percentage range from 38 to $43 \%$ and protein content range from 27 to $32 \%$ (Gugel and Falk, 2006). The health friendly oil properties of Camelina sativa could be evaluated by the fact oil contains omega-3fatty acid, a potentially rich substance to lower down cholesterol level (Korvenon et al., 2002). In North America, it was mainly known as a wild flax (Lafferty et al., 2009).

The agronomic and breeding potential of this crop has not 
been fully examined (Hunter and Roth, 2010). It is resistant to draught (Kyung et al., 2013), and also cold resistant (McVay and Khan, 2011), effective user of nutrients, and a short duration crop. The camelina's oil is equally beneficial for humans as well as animals. Due to low cultivation cost and rich in oil content, also been used quiet often in biofuel industry (Agarwal et al., 2010). Our today knowledge of advance and modern cropping system along with new oil seed crops, accelerates our interest in Camelina sativa (Rehman et al., 2014).

Camelina sativa is an annual crop which can be cultivated in both, summer and winter seasons. Depending over nutrient availability the height of the plant is around 60 $\mathrm{cm}$ to $100 \mathrm{~cm}$. There is no dormancy of seeds (Ehrensing and Guy, 2008). However, the plant is comparatively more disease susceptible and potentially les competitive to weeds sown in winter (Zubr, 1997). Moreover, the plant is unable to perform well on wet or poorly drained soils, which favors disease incidence (Hunter, 2010).

The crop could be successfully grown on variety of soils. However, heavy, water logged, acid soils and lands having severe weed problem are not suitable for Camelina sativa cultivation (Lo ák et al. (2011). Comparatively with rapeseed, it is more resistant undesirable climatic conditions primarily drought and low temperature (Vollmann et al., 2007). Moreover, camelina sativa pods are shatter free a unique character which makes it the best choice for mechanical harvesting.

The soils of Pakistan are mostly dry with less organic matter (0-1\%), high concentration of calcium carbonate and a low concentration of organic matter. That calcium carbonate makes our soil alkaline with $\mathrm{pH} 8$ or above. So use of the balanced nutrients for optimum yield is necessary (Khan, 2003). High yielding and good quality of Camelina sativa production mostly depends on balanced nutrition and growing condition. In our country, the farmers are only focusing on fertilization of macronutrients NPK, while neglecting the importance and essentiality of micronutrients (Rashid and Rafiq, 1998). Low quantity of micronutrients required by plant, but their deficiency affects all fundamental biochemical and physiological process and reduce the crop yield (Imtiaz et al., 2010).

Silicon (Si) has not been proven to be an essential element for higher plants, but its beneficial effects on growth have been reported in a wide variety of crops, including rice, wheat, barley, and cucumber. Si is especially important for healthy growth and high and sustainable production of Camelina sativa, which is a typical Si-accumulating plant. Si fertilizer is applied to crops in several countries for increased productivity and sustainable production. Plants take up Si in the form of silicic acid, which is transported to the shoot, and after loss of water, it is polymerized as silica gel on the surface of leaves and stems. Evidence is lacking concerning the physiological role of Si in plant metabolism.

\section{MATERIALS AND METHODS}

A pot experiment was performed to check the effect of different concentrations of Silica gel on the growth and yield parameters of Camelina sativa L. Planting was done on $20^{\text {th }}$ Dec, 2016 at Outside Nanotechnology Laboratory, Department of Agronomy, PMAS Arid Agriculture University Rawalpindi.

\section{Methodology}

\begin{tabular}{ccc}
\hline Treatments & (mgs of Silica gel/ gram of Soil) \\
\hline $\mathrm{T}_{1}=$ Control & e.g & $0.0 \mathrm{~g} / 4 \mathrm{~kg}$ \\
$\mathrm{~T}_{2}=0.15 \mathrm{mg} / \mathrm{g}$ & e.g & $0.6 \mathrm{~g} / 4 \mathrm{~kg}$ \\
$\mathrm{~T}_{3}=0.30 \mathrm{mg} / \mathrm{g}$ & e.g & $1.2 \mathrm{~g} / 4 \mathrm{~kg}$ \\
$\mathrm{~T}_{4}=0.45 \mathrm{mg} / \mathrm{g}$ & e.g & $1.8 \mathrm{~g} / 4 \mathrm{~kg}$ \\
$\mathrm{~T}_{5}=0.60 \mathrm{mg} / \mathrm{g}$ & e.g & $2.4 \mathrm{~g} / 4 \mathrm{~kg}$ \\
\hline
\end{tabular}

Black Polythene Bags were used with dimensions of 8 inches' width and 12 inches' length (depth), capable of having soil $4 \mathrm{~kg} / \mathrm{bag}$ and Silica gel 18 grams were used in the experiment.

Uniformly ground soil was selected and analyzed particularly for Silicon. Above mentioned concentrations were prepared and mixed thoroughly in individual bag soil lots. Bags were filled properly. Experimental design contained three replications, each having all the five treatments.

10 seeds of Camelina stiva L. were sown in each Polythene Bag. Irrigation was made after sowing. The bags were left in open conditions to study crop's behavior under natural environmental conditions. Daily weather Data were collected and readings for different parameters were recorded as per the recommendations.

\section{AGRO -MORPHOLOGICAL PARAMETERS Germination Percentage}

Calculations for germination were made on $27^{\text {th }}$ Dec, 2016. Total germinated seeds were counted and percentage for germination was calculated from total seed sown.

\section{Shoot and Root Length}

Plants taken were washed thoroughly and length was 
calculated in $\mathrm{cm}$ for shoot and root.

\section{Shoot and Root Biomass}

Plants were washed thoroughly, and shoots were separated from roots with the help of scissors and weighed separately.

\section{Relative Water Content of Leaf (RWC)}

Leaves of normal size were dissected form plants of each treatment and washed with water followed by cool drying for 15 minutes at room temperature. Relative Water Content (RWC) of leaf was calculated according to the following formula:

Relative Water Content $(\mathrm{RWC})=\underline{\mathrm{FW}}-\mathrm{DW}$ TW - DW

Where,

FW $=$ Fresh weight of Leaf in $g$

TW $=$ Turgid weight of rehydrated fresh leaf after keeping in water for $2-3$ hours @ $25^{\circ} \mathrm{C}$.

DW $=$ Dry weight of leaf after keeping in oven at $70^{\circ} \mathrm{C}$ for about 24 hours.

\section{Leaf Membrane Stability Index (LMSI)}

It was calculated further by following the methodology proposed by George, et al. 2015. For this, two leaf strips of $0.1 \mathrm{~g}$ from plants of each treatment were taken and put into a test tube having $10 \mathrm{ml}$ distilled water. One test tube e.g sample 1 , was kept in water bath at $40^{\circ}$ $\mathrm{C}$ for 30 minutes and its electrical conductivity e.g C1 was calculated. Second test tube containing sample 2, was kept in boiling water bath at $100^{\circ} \mathrm{C}$ for 15 minutes and its electrical conductivity e.g $\mathrm{C} 2$ was calculated. This process was repeated for all treatments and LMSI was calculated as follows.

Leaf Membrane Stability Index (LMSI) $=1-(\mathrm{C} 1 / \mathrm{C} 2) 100$

\section{RESULTS AND DISCUSSION Germination Percentage}

Analysis of Variance (ANOVA) for germination count of Camelina sativa showed significant difference among various treatments (figure 1). The highest germination $(80 \%)$ count was recorded in treatment where, $0.45 \mathrm{mg} / \mathrm{g}$ silica gel was applied. Moreover, the $\mathrm{T}_{5}, 0.60 \mathrm{mg} / \mathrm{g}$ silica gel $(76.67 \%)$ and $\mathrm{T}_{3},(73.33 \%)$ followed by $\mathrm{T}_{2}$ (63.33) while the minimum germination count was recorded in control treatment (53.33\%). The graphical analysis is shown in figure 1.

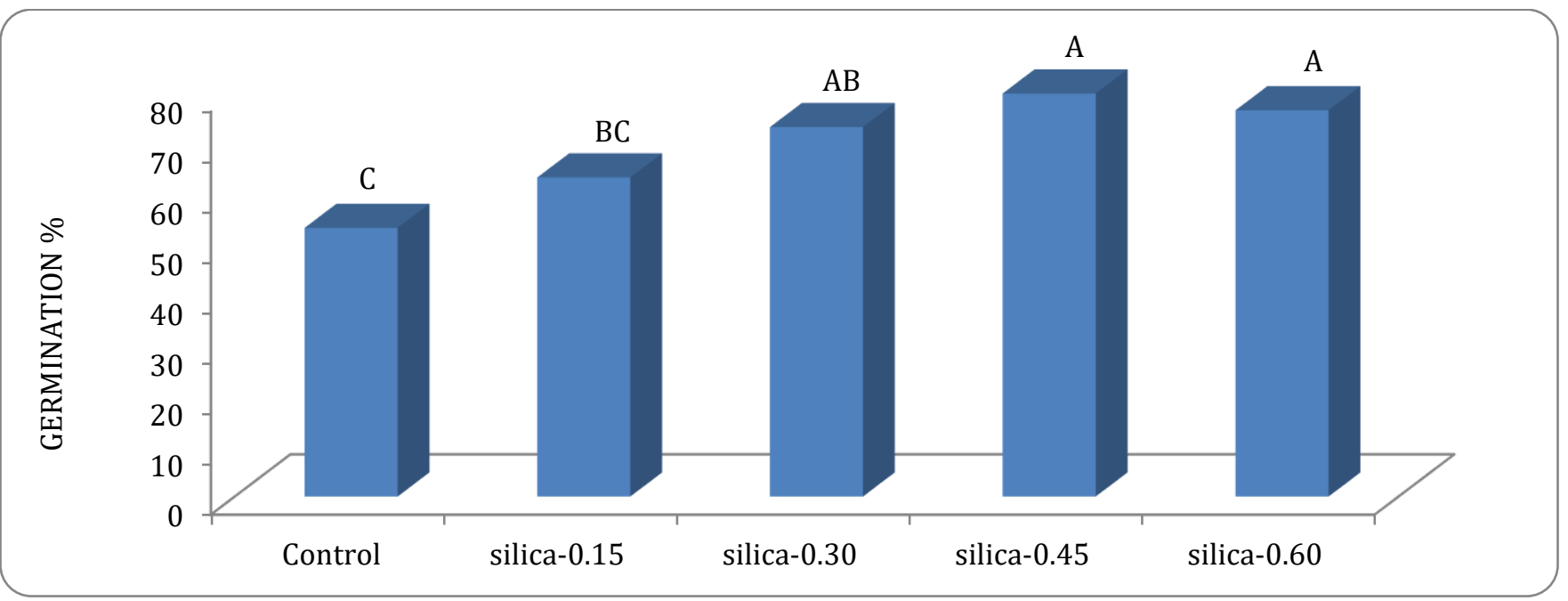

Figure 1. Effect of silica gel on seed germination of Camelina sativa.

\section{Root Length (cm)}

Analysis of Variance (ANOVA) for root length of camelina sativa plant studied under pot experimental condition indicated that all treatments possessing highly significant differential capability for affecting root length.

Analysis of means values (LSD), at 5\% level of significance, indicated that highest mean value (6.76) root length of Camelina plant was recorded in treatment 5 comprising the application by $0.60 \mathrm{mg} / \mathrm{g}$ silica gel.
Moreover, the least mean value (4.07) was recorded in control. The range for number of siliquae per plant is 5.16 to 4.76 and 3 distinct classes were formed for root length per plant. The graphical analysis is shown in figure 2 .

\section{Shoot length (cm)}

Highest mean value (35.33) for shoot length was recorded in treatment 4 comprising the application of silica gel by $0.60 \mathrm{mg} / \mathrm{g}$. Moreover, second highest mean value (31.67) treatment 4 comprising of $0.45 \mathrm{mg} / \mathrm{g}$ silica 
gel application. The least mean value (24.33) was recorded in control depriving of micronutrient foliar application. The range for number of branches per plant is 29-27 and 2 distinct classes were formed for shoot length of Camelina plant. Similar kind of observation was observed by George, et al. 2015 in which effect of water stress in tomato was studied. The graphical analysis is shown in figure 3.

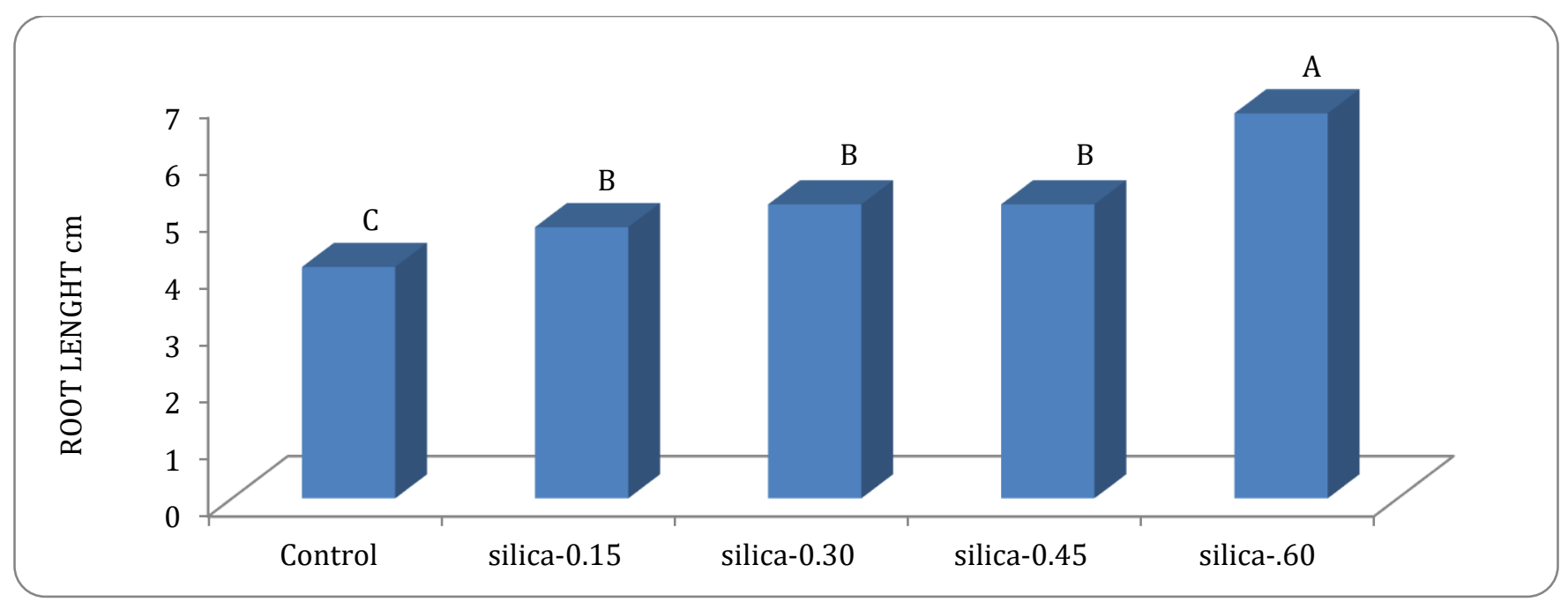

Figure 2. Effect of silica gel on root length $(\mathrm{cm})$ of Camelina sativa.

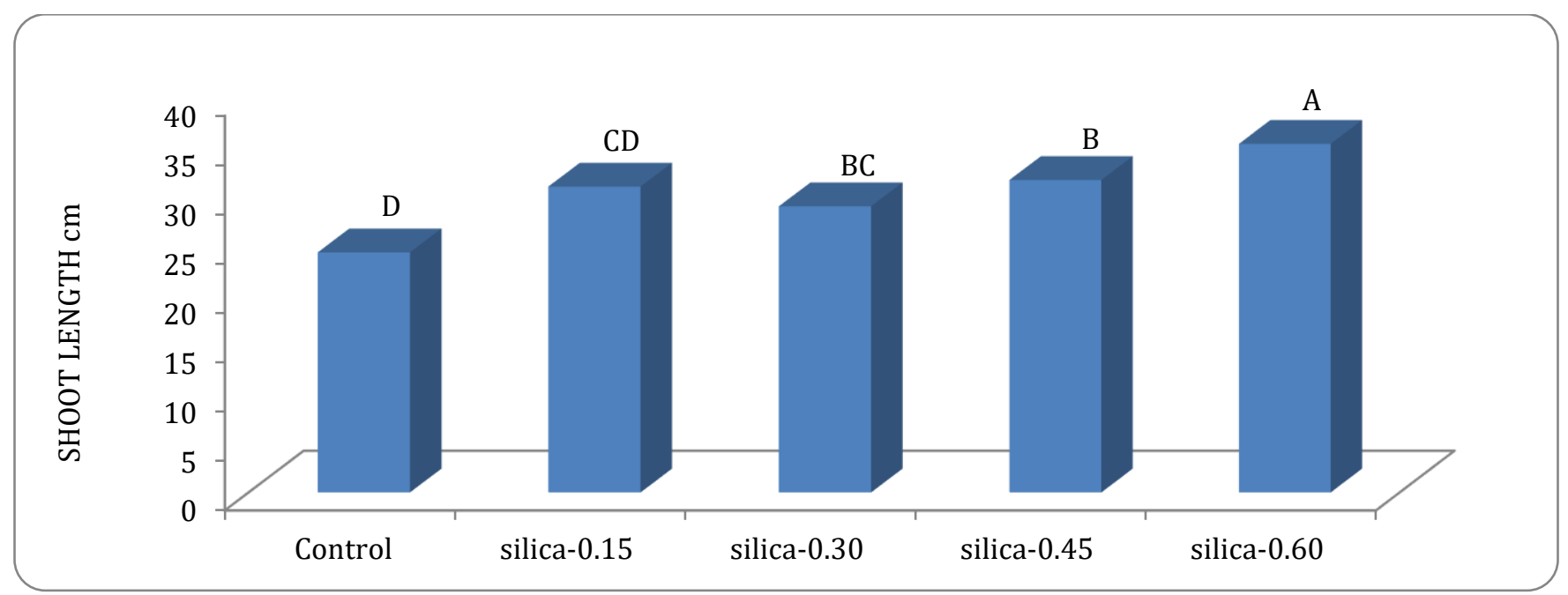

Figure 3. Effect of silica gel on shoot length $(\mathrm{cm})$ of Camelina sativa.

\section{Root Biomass}

Root biomass of Camelina sativa was significantly affected by silica gel application. The maximum root biomass of plants was observed in treatment 5 where $0.60 \mathrm{mg} / \mathrm{g}$ silica gel (1.7) g. The minimum root biomass was visible in control $(0.85) \mathrm{g}$. Rest of the treatments produced plants with heights range of (1.34 to 1.06) g. The maximum root biomass gained in $\mathrm{T}_{5}$ could be due to balance availability of required element. The graphical analysis is shown in figure 4 .

\section{Shoot Biomass}

Highest mean value (5.57) for shoot biomass was recorded in treatment 5 comprising the silica gel application by 0.60 $\mathrm{mg} / \mathrm{g}$. Moreover, second highest mean value (4.63) treatment 4 comprising of $0.45 \mathrm{mg} / \mathrm{g}$ silica gel application respectively. The least mean value (3.33) was recorded in control depriving of silica gel application. The range for shoot biomass is 4.3-4.03 and 2 distinct classes were formed. The graphical analysis is shown in figure 5 . 


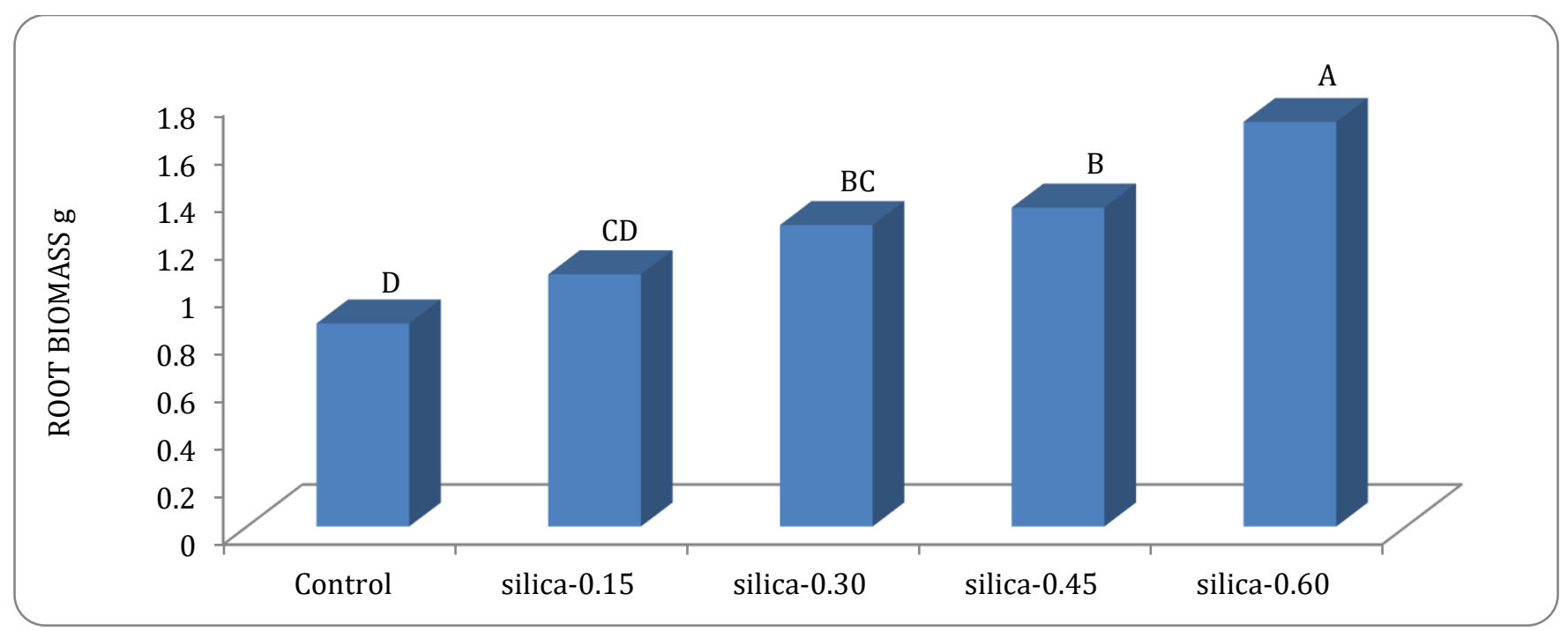

Figure 4. Effect of silica gel on root biomass.

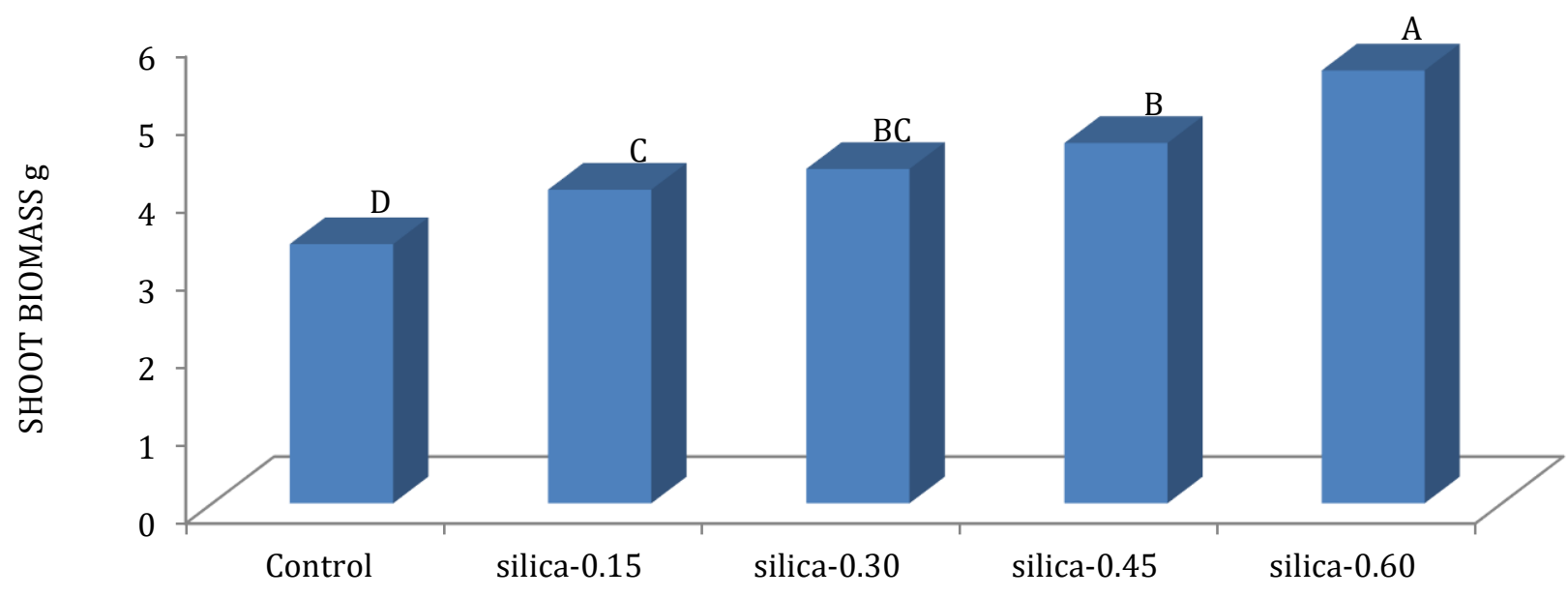

Figure 5. Effect of silica gel on shoot biomass of Camelina sativa.

\section{Relative Water Content of Leaf (RWC}

Highest mean value (0.6983) relative water content of leaf was recorded in treatment 5 comprising the silica gel application by $0.60 \mathrm{mg} / \mathrm{g}$. Moreover, second highest mean value (0.5133) treatment 4 comprising of $0.45 \mathrm{mg} / \mathrm{g}$ silica gel application. The least mean value (0.27) was recorded in control depriving of silica gel application. The range for relative water content is $0.4633-0.3767$ and 2 distinct classes were formed for relative water content of leaf. Similar results were observed by George, et al. 2015 in which effect of water stress in tomato was studied. The graphical analysis is shown in figure 6 .

\section{Leaf Membrane Stability Index (LMSI)}

Highest mean value (7.07\%) relative water content of leaf was recorded in treatment 5 comprising the silica gel application by $0.60 \mathrm{mg} / \mathrm{g}$. Moreover, the least mean value $(4.30 \%)$ was recorded in control depriving of silica gel application. The range for relative water content is $(6.23$ to $6.17 \%$ ) and 2 distinct classes were formed for relative water content of leaf. Similar kind of observation was observed by George, et al. 2015 in which effect of leaf membrane stability index in tomato was studied. The graphical analysis is shown in figure 7. 


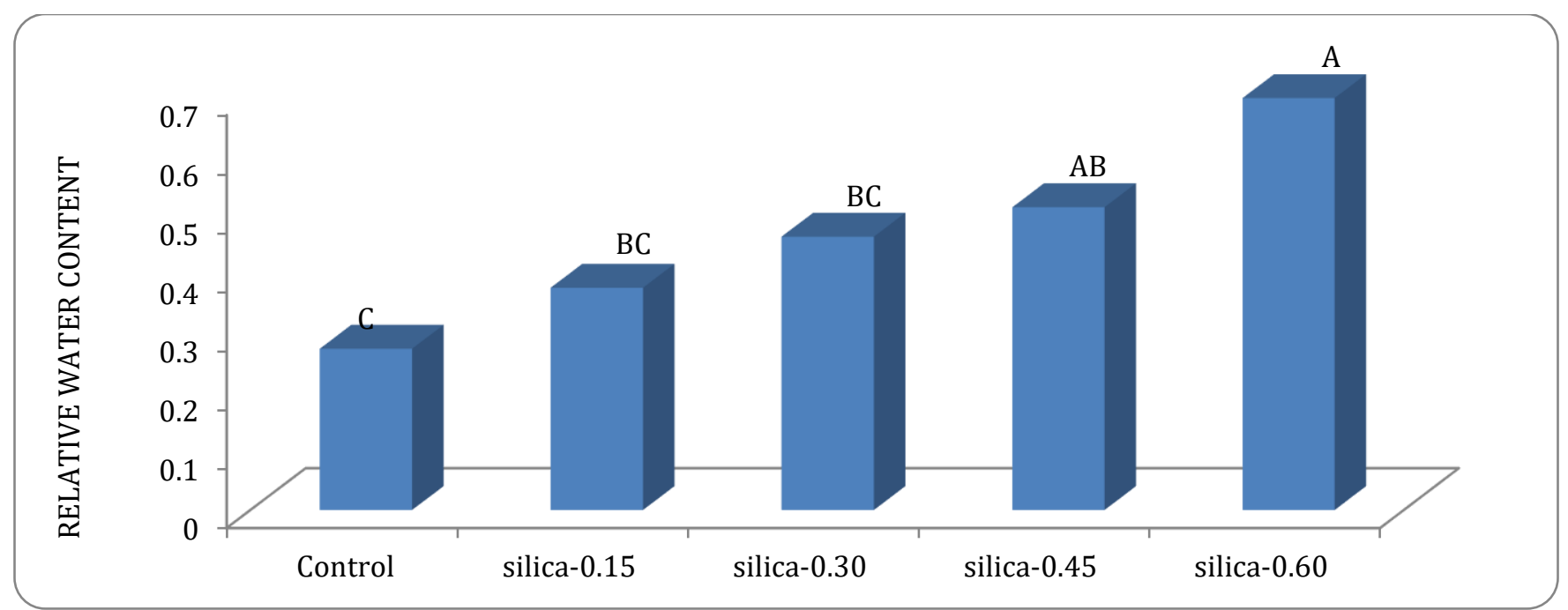

Figure 6. Effect of silica gel on relative water content of Camelina sativa.

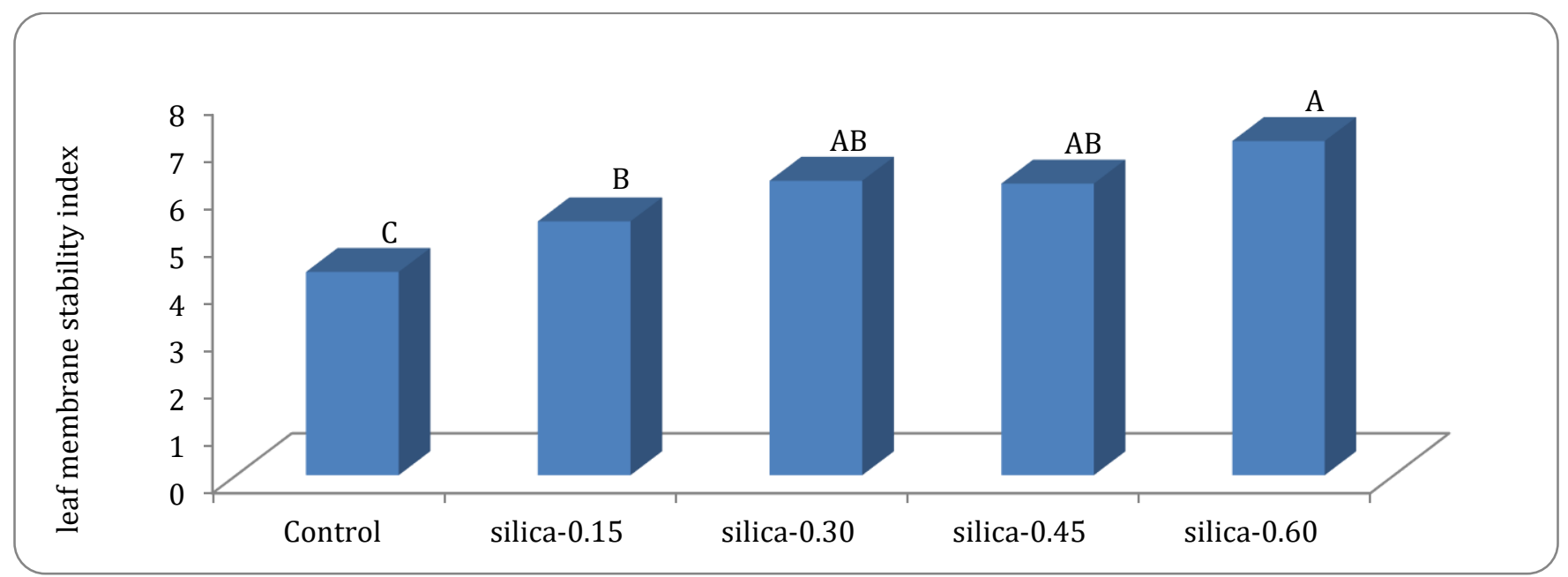

Figure 7. Effect of silica gel on leaf membrane stability index of Camelina sativa.

\section{CONCLUSION}

The study concluded that significant effect of silica gel application is crucial and important to improve vegetative attributes of false flax. Application of silica gel significantly increased the seed germination $(80 \%)$, root length $(6.67) \mathrm{cm}$, shoot length $(35.33) \mathrm{cm}$, root biomass (1.7) g, shoot biomass (5.57) g, relative water content of leaf (0.69) and leaf membrane stability index (0.07).

\section{REFERENCES}

Abbas. M., M. W. Akram., I. Saeed and A. Bashir. 2010. Economic of non- conventional oil seed crops in Central Punjab. Pakistan J. Agricultural Research, 23(3-4): 132-136.

Agarwal, A., T. Pant and Z. Ahmed. 2010. Camelina sativa:
A new crop with biofuel potential introduced in India. Current Science. 99(9):1194-1195.

Ehrensing, D. T., and S. O. Guy. 2008. Camelina, Oilseed Crops. Oregon State University Extension Service.

George, S., M. M. Nasir, A. J. Shakeel, Sadar udian Siddique and G. Abdul. 2015. impact of polyethyelene glycol on proline and membrane stability index for water stress regime in tomato. Pak. J. Bot., 47(3): 835844.

Gugel, R. K., and K. C. Falk. 2006. Agronomic and seed quality evaluation of Camelina sativa in western Canada." Canadian journal of plant science 86(4): 1047-1058.

Hornedo, R., J. V. M. Sánchez, L. Bedmar, P. Benito and A. D. Arroyo. 2015. Effect of the residual organic and 
mineral fertilizer on biological and agricultural yield, protein and oil content in the seeds of camelina plant (Camelina sativa). Revista Internacional de Contaminación Ambiental. Vol.31 (4) pp.377-387.

Hunter, J., and G. Roth, .2010. Camelina production and potential in Pennsylvania. Penn State College of Agricultural Sciences.

Imtiaz, M., A. Rashid, P. Khan, M. Y. Memon and M. Aslam. 2010. The role of micronutrients in crop production and human health. PAK. J. Bot., 42(4):2565-2578.

Karvonen, H. M., A. Aro, N. S. Tapola, I. Salminen, M. I. Uusitupa and E. S. Sarkkinen. (2002). Effect of alpha-linolenic acid rich Camelina sativa oil on serum fatty acid composition and serum lipids in hypercholesterolemic subjects. MetabolismClinical and Experimental, 51(10), 1253-1260.

Khan, H. R., G. K. Mcdonald and Z. Rengal. 2003. Zinc fertilization improves water use efficiency, grain yield and seed $\mathrm{Zn}$ content in chickpea soil. 249(2):289.

Khan, S., H. Rehman, M. A. Wahid, M. F. Saleem, M. A. Cheema, S. M. A. Basra and M. Nadeem. 2016. Boron fertilization improves seed yield and harvest index of Camelina sativa L. by affecting source-sink. J. Plant Nutrition. Vol. 39(12):1681-1687.

Kyung, J. K., H. Kang, K. H. Han, and S. J. Ahn. 2013. Molecular cloning, characterization and stressresponsive expression of genes encoding glycinerich RNA-binding proteins in Camelina sativa $\mathrm{L}$. Plant Physiology and Biochemistry 68:44-51.

Lafferty, R. M., C. Rife, G. Foster. 2009. Spring camelina production guide for the central high plains. Blue Sun Biodiesel special extension publication.

Lošák, T., J. Hlusek, J. Martinec, J. Vollmann, J. Peterka, R. Filipcik, L. Varga, L. Ducsay and A. Martensson. 2011. Effect of combined nitrogen and sulphur fertilization on yield and qualitative parameters of Camelina sativa L. Crtz.(false flax). Acta Agriculturae Scandinavica, Section B-Soil \& Plant Science, 61(4), pp.313-321.

Lu, C., J. Kang. 2008. Generation of transgenic plants of a potential oilseed crop Camelina sativa by Agrobacterium-mediated transformation. Plant cell Reports. Vol. 27(2):273-278.

Matthaus, B. and J. Zubr. 2000.Variability of specific components in Camelina sativa oilseed cakes. Ind
Crops Prod 12: 9-18.

McVay, K. A. and Q. A. Khan. 2011.Camelina yield response to different plant populations under dryland conditions. Agronomy Journal, 103, 4, 1265.

Pan, X., R. Lada, C. D. Caldwell and K. C. Falk. 2011. Photosynthetic and growth responses of Camelina sativa (L.) Crantz to varying nitrogen and soil water status. Photosynthetica. Vol. 49(2):316-320.

Pavlistaa, A. D, G. W. Hergerta, J. M. Margheima, T. A. Isbellb. 2016. Growth of spring camelina (Camelina sativa) under deficit irrigation in Western Nebraska. Industrial Crops and Products. Vol. 83, pp 118-123.

Pourgholam, M., N. Nemati and M. Ovesyi. 2013. Scholars Research Library, India, Annals of Biological Research, 4(7):200-203.

Putnam, D. H., J. T. Budin, L. A. Field and W. M. Breene. (1993). Camelina: a promising low-input oilseed. New crops. Wiley, New York, 314.

Rashid, A. and E. Rafiq. 1998. Micronutrients in Pakistan Agriculture: Significance and Use. PARC, Islamabad Pakistan. p. 8.

Rehman, H. V., M. A.Wahid, M. F. Saleem, M. A. Chemma, S. M. A. Basra and M. Nadeem. 2015. Boron fertilization improve the seed yield and harvesting index of camelina sativa $\mathrm{L}$. by affecting source-sink. J. plant. Nutrition.

Rehman, H.V., M.A.Wahid, M.F. Saleem, M.A. Chemma, S. M. A. Basra, and M. Nadeem. 2015. Boron fertilization improve the seed yield and harvesting index of camelina sativa L. by affecting source-sink. J. plant. Nutrition.

Usher, S., R. P. Haslam, N. Lopez and O. A. Napier. 2015. Field trial evaluation of the accumulation of omega3 long chain polyunsaturated fatty acids in transgenic Camelina sativa: Making fish oil substitutes in plants. Metabolic Engineering Communications. Vol. 2, pp 93-98.

Vollmann, J., A. Damboeck, A. Eckl, H. Schrems and P. Ruckenbauer. 1996. Improvement of Camelina sativa, an underexploited oilseed. ASHS Press, Alexandria, VA, USA. pp: 357-362.

Vollmann, J., T. C. Moritz, S. Kargl, S. Baumgartner, and H. Wagentristl. 2007. Agronomic evaluation of camelina genotypes selected for seed quality characteristics. Industrial Crops Production 26:270-277. 
Wang, L. X., X. F. Sen and Y. H. Wang. 2007. Effects of B, Mo, $\mathrm{Zn}$ interaction on the seed yield and quality of Brassica napus. Jr. of Plant Nutrition and Fertilizer. Vol: 13(2): pp:318-323.

Waraich, E. A., A. Zeeshan, A. Rashid, Saifullah, S. Muhammad and Ehsanullah. 2016. Modulation in growth, development, and yield of Camelina sativa by nitrogen application under water stress conditions. J. plant nutrition 40(5): 726-735.

Waraich, E. A., Z. Ahmed, R. Ahmad, M. Y. Ashraf Saifullah, M. S. Naeem, and Z. Rengel. 2013. Camelina sativa, a climate proof crop, has high nutritive value and multiple-uses: a review. Australian Journal of Crop Science 7:1551-1559.

Zubr, J. 1997. Oil-seed crop: Camelina sativa. Industrial Crops and Products. 6: 113-119.

Zubr, J. 2003. Dietary fatty acids and amino acids of Camelina sativa seed. Journal of Food Quality. 26 (6): 451-462.

Zubr, J. 2003. Qualitative variation of Camelina sativa seed from different locations. Industrial Crops Products. 17 (3): 161-169.

Publisher's note: EScience Press remains neutral with regard to jurisdictional claims in published maps and institutional affiliations.

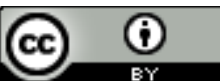

Open Access This article is licensed under a Creative Commons Attribution 4.0 International License, which permits use, sharing, adaptation, distribution and reproduction in any medium or format, as long as you give appropriate credit to the original author(s) and the source, provide a link to the Creative Commons license and indicate if changes were made. The images or other third-party material in this article are included in the article's Creative Commons license, unless indicated otherwise in a credit line to the material. If material is not included in the article's Creative Commons license and your intended use is not permitted by statutory regulation or exceeds the permitted use, you will need to obtain permission directly from the copyright holder. To view a copy of this license, visit http://creativecommons.org/licenses/by/4.0/.

(C) The Author(s) 2020. 